\title{
Ethnobotanical Study of Toxic Plants in Ngadiwono Village, Tosari District, Pasuruan Regency, East Java
}

\author{
Anggraeni Oktavia ${ }^{1 *}$, Serafinah Indriyani ${ }^{2}$, Jati Batoro ${ }^{2}$ \\ ${ }^{1}$ Postgraduate Program, University of Brawijaya, Malang, Indonesia \\ ${ }^{2}$ Department of Biology, Faculty of Mathematics and Natural Sciences, University of Brawijaya, Malang, Indonesia
}

\begin{abstract}
The society in Ngadiwono village is part of Tengger tribe that depends on their surrounding environment on fulfilling the life necessities. However, the society knowledge obout toxic plant has never been revealed. Therefore, the main objective of this study is to documenting the toxic plants in Ngadiwono village according to society knowledge and scientific study on its toxic content. This study was conducted in Ngadiwono Village, Tosari District, Pasuruan Regency. The informants were chosen by using snowball method $(n=14)$. Interview was conducted using semi-structural method. The collected data was analysed to obtain ICS value (Index Cultural Significance) and UVs (Use Value). The identification of toxic compound was based on previous study. The study result identified 8 plants that considered to be toxic by local society: bedor (Girardinia palmata Blume.), yellow kecubung (Brugmansia suaveolens Bercht. \& J.Presl), white kecubung (Brugmansia suaveolens Bercht. \& J.Presl ), jarak (Ricinus communis L.), yellow terpasan (Cestrum elegans (Brongn.) Schltdl), red terpasan (Cestrum elegans (Brongn.) Schltdl), kudisan (Euphorbia pulcherrima Willd.), and ciplukan (Physalis peruviana L.). The highest ICS value was found in jarak (Ricinus communis). Meanwhile, the lowest ICS value was found in yellow and red terpasan (Cestrum elegans) due to its minimum use by local society. The highest UVs was found in kudisan.
\end{abstract}

Keywords: Ethnobotany, Ngadiwono, Plant, Tengger, Toxic

\section{INTRODUCTION}

The society in Ngadiwono village, part of Tengger tribe, lives in the area of Bromo Tengger Semeru National Park (BTSNP). Most of Tengger society depends on their surrounding environment in occupying their life necessities [1] [2]. Meanwhile, the knowledge of local society is influenced by the local history, custom, and natural resources. In recent years, activities aimed at collecting information, documenting, and confirming the use of ethnomedicine for traditional treatment have been widely conducted in Tengger [2]. Half of the published paper is related with the biological activities of plants, including antimicrobial, molluscicidal, antimalarial, toxicological, and anti-tumor related activities [3]. Previous study mentioned that BTSNP has approximately 118 species of medicinal plants that could be used to medicate 60 types of diseases [4]. However, the knowledge of local society about toxic plants has never been revealed or researched. Therefore, the objective of this study is to documenting the toxic plant in Ngadiwono village according to society knowledge and scientific study about its content that influenced the toxicity.

\section{MATERIAL AND METHOD}

This study was conducted in Ngadiwono Village, Tosari District, Pasuruan Regency, East Java Province, Indonesia (34 $20^{\prime} 35.29^{\prime \prime} \mathrm{E}-$ $\left.35^{\circ} 09^{\prime} 27.04^{\prime \prime} \mathrm{E} ; \quad{ }^{\circ} 05^{\prime} 19.12^{\prime \prime} \mathrm{N}-0^{\circ} 53^{\prime} 53.81^{\prime \prime} \mathrm{N}\right)$. Ngadiwono village is a buffer zone in Bromo Tengger Semeru National Park that consists of 4 regions: Ledoksari, Krajan, Ketuwon, and Banyu Meneng. Total area of Ngadiwono village is 639.03 hectares with the lowest temperature of $10^{\circ} \mathrm{C}$. The distance between settlement area and forest is $2 \mathrm{~km}$. Total male population in BTSNP was 1097, while female was 1474 [5].

\section{Data Collection}

Data was collected by using semi-structural and deep interview. The informants were chosen

\footnotetext{
Correspondence address:

Anggraeni Oktavia

Email : anggraeni_oktavia@yahoo.com

Address : Rajawali no. 14 Sukun Malang East Java
} 
according to snowball method $(n=14)$. We were accompanied by local people during the research, especially when collecting the toxic plants. We terminated the data collection when we already obtained saturated data.

The interview result was analysed to obtain the use value of toxic plant using ICS (Index Cultural Significance). ICS value is an important factor that influencing the presence and use of plants. ICS value was calculated according to the formula listed in the Manual of Flora Diversity Data Collection [6].

$$
\operatorname{ICS}=\sum{ }_{\mathrm{i}}={ }_{1}(q \times i \times e) n_{1}
$$

Where: ICS = Index Cultural Significance, is the sum of one individiual "use" value from 1 to $\mathrm{n} ; \mathbf{q}=$ quality value, is calculated by giving score based on individual plant quality under the criteria: 5 (primary food), 4 (secondary food or primary material), 3 (other food material or medicinal plant), 2 (used in a ritual, mythology, or recreation) and 1 (infrequent use/mere recognition); $\mathbf{i}=$ intensity value, is the intensity of use under the criteria: 5 (very high intensity), 4 (high intensity), 3 (moderate intensity), 2 (low intensity) and 1 (very low intensity); e = exclusivity value, conditions: 2 (the most favored plants that become the main preferences and could not be replaced), 1 (the favored plants but could be replaced by other species of plants) and 0,5 (the beneficial plants that become the secondary preferences).

The obtained data was analysed quantitatively by using UVs equation:

$$
\text { UVis }=\frac{\sum \text { iUis }}{\text { nis }}
$$

Where: Uvs = total number of use that stated by the informant (i) for each plant species (s) in every interview; nis = total number of interview with informant (i) for each plant species (s).

\section{RESULT AND DISCUSSION}

The majority of informants were aged over 30 years old with the main occupation as farmer or cattleman (cows or pigs). With respect to the occupation, the informants were predicted to be very accustomed with plant species that could endanger the livestock and considered to be very selective on choosing plants for the feed. They usually use herbicide to inhibit the growth of toxic plant or just cut the plants.
According to the result study, 8 plants were considered to be toxic by the society of Ngadiwono Village (table 1): bedor (Girardinia palmata), yellow kecubung (Brugmansia suaveolens), white kecubung (Brugmansia suaveolens), jarak (Ricinus communis L), yellow terpasan (Cestrum elegans), red terpasan (Cestrum elegans), kudisan (Euphorbia pulcherrima), ciplukan (Physalis peruviana).

Bedor was very hard to find in farms. However, this plant still easy to be found near the river, ravine, or forest edge. In addition, terpasan (Cestrum elegans) also considered to be toxic by local society. There are 3 types of petal on terpasan, purple, red or black, and yellow. Interestingly, the purple terpasan was used as food for livestock. Meanwhile, the red or yellow terpasan was believed to cause poisoning in the livestock with indications of bloated stomach and the appearance of foam from mouth. If they were not treated immediately, they would meet the worst case, mortality.

Kecubung (Brugmansia suaveolens) also considered to be toxic by the local society. There are 3 types of kecubung in Ngadiwono Village: kecubung with yellow petal, kecubung with double white petals, while the last is kecubung with single white petal. The double white petal kecubung was used for feeding the livestock and considered to be non-toxic. We found that local society used water inside the flower buds as eye drops. In contrary, kecubung with single white petal, also called as black kecubung, and yellow petal were believed to be toxic by the society. The society did not used both kecubung for feeding the livestock due to its effect that would cause bloated stomach and puke. In addition, it would cause headache and hallucination if it is consumed by human.

Ciplukan (Physalis peruviana) was considered to be toxic by the society in Ngadiwono village. Ciplukan would cause bloated stomach for those livestock that consumed it. The side effect was shown by a swelling belly. In contrary, the leaves and fruits of ciplukan could be consumed by human and were believed to be a medicine for diabetes.

Kudisan (Euphorbia pulcherrima) could be easily found as decorative plants. The exposure of kudisan sap would induce itchiness to the skin, therefore, the society classified kudisan as toxic plant. The side effect of kudisan exposure became the main reason for its local name (kudis = mange). 
The use of toxic plants by society was calculated using ICS (Index Cultural Significance). The highest ICS value was found in jarak (45). The result demonstrated that jarak plant was very well known and broadly used by the society. Jarak seeds usually used at traditional ceremony called entas-entas. In addition, jarak seeds contained oil that could be used for fireplace material. Jarak seeds also used as a lighting at the burial of the baby umbilical cord. This seeds became an important requirement that must be brought while visiting a shaman. A small quantity of jarak seeds (3-5 seeds) could be used as seasoning. The wood also useful as firewood.

Tengger tribe has some unique characteristics compared to other tribe in Java. The majority of Tengger society is centered on the Hindu-Budha religion combined with the traditional customs and beliefs, moreover they still holding tight to their traditional beliefs until now. The society uses plants on their traditional ceremony as sesajen (the sacred food) or as symbols of an activity.

Tengger society used bedor (ICS $=12$, Uvs = 1.077) for a ritual dance called jaran kepang. Bedor was struck or given as food for the dancer to assure that they are truly possessed by the spirit, so they become resistant to the itchiness and burning sensation generated by bedor. According to the informant, the itchiness could be treated by spreading ganjan leaves (Artemesia vulgaris) that has been squeezed to the exposured skin.

The stem of white and yellow kecubung (ICS = 24, UVs $=1.33$ ) was used to support pipes of an irrigation system in the farm and as firewood. Beside that, kecubung that grew near the water resources was believed to maintain the quality and quantity of water.

The leaves and fruits of ciplukan (ICS = 9; UVs $=0,835$ ) could be consumed. The society believed that this plant could be used as a medicine for diabetes. Kudisan leaves (ICS $=12$, Uvs $=1,65$ ) were consumed by the society as krawu (mixed vegetable) or as a stuffing in pork belly dish. In contrary, terpasan has never been used by the society. The society preferred to prevent the growth of terpasan by using herbicide or cut the plants.

The common symptoms of poisoning cases on the livestock were indigestion, such as bloated or swollen stomach. Toxic plants mentioned by the society consist of alkaloids, steroids, and terpenes, that acted as a poison for the stomach. Recent study conducted by Fahrauk et al. [7] stated that LC 50 of ethanol extract on terpasan
(Cestrum nocturnum) was $44.9658 \mu \mathrm{g} / \mathrm{ml}$. In fact, this ethanol extract was potentially toxic for Artemia salina due to its LC 50 value that was less than $1000 \mathrm{\mu g} / \mathrm{ml}$. The compound on terpasan extract consisted of alkaloids, flavonoid polyphenols, tannins, saponins, monoterpene and sesquiterpenes, also steroids and terpenoids. All of these compounds were proven on interfering the digestion system of shrimp larvae after a series of experiments. These compounds worked by inhibiting the sensory receptors, so the larvae fail to get the stimulus and unable to recognize their food.

The society avoided jarak for feeding the livestock due to its effect. A certain amount of jarak was able to poisoning human. Anuj [8] discovered the toxic compound of other plant that belong to jarak family (Jatropa curcas). Latex in seeds contains proteolytic enzymes, curcin and octapeptide, curacycline A, which shows anticomplementary activity. Seed oil contains curcanoleic acid or jatrophin. As well as Ricinus communis, jarak also contains ricin, such as toxalbumin, phorbol, and cyanic acid, that caused hepatotoxicity in human. The greatest toxic content was found in the seed of Ricinus communis. In fact, toxalbumin inhibits the synthesis of 14 proteins, and further effect is gastroenteritis or inflammation on the digestive track. The symptom of toxalbumin poisoning is burning sensations in the throat, stomachache, nausea, vomit, diarrhea, dehydration, lethargy, sleepy, and shock. Other study also mentioned other symptom, such as muscle twitching and an excessive saliva. The toxic effect depends on the doses, whereas the consumption of three seeds could cause a temporary or mild symptom. Moreover, the roasted seed could worsen the effect. Indonesia National Agency of Drug and Food Control [9] described that curcin and ricin would cause a severe gastrointestinal inflammation, characterized by hemorrhage, irritate the gastric mucosa and influence the blood clotting process. The other chemical compound in jarak seed is gallic acid, that could cause stomach irritation and kidney failure in a certain amount. First aid for gallic acid poisoning is not to induce vomiting because it could trigger irritation on the gastrointestinal track. For conscious victims, it's better to ask them swallow an activated carbon in less than 4 hours after the exposure. Activated carbon could assist the toxin absorption. The poisoning symptoms generally appear after 1-6 hours after consuming jarak seed. Hepatotoxicity occurs 48-71 hours after the toxic material being 
consumed. There is no antidotes found for jatropha seed poisoning yet.

Tengger society explained that kecubung plant (Brugmansia suaveolens) could cause poisoning on the livestock with symptoms bloated and swollen stomach, and then enervation. Moreover, consuming the roasted seed could induce a hallucinatory effect. A study by Yoon (2014) revealed an accident experienced by koreans. Yoon explained that a korean used kecubung flower as a food decorator on bibimbap (traditional food) and eat a few of it. What happen next was he/she lost consciousness for approximately 10 hours. Kecubung contains trophic alkaloids, such as scopolamine, hyoscyamine and atropine. The worst case is all parts of kecubung contain toxin, expecially in the roots and seeds [10]. Alkaloids in plants, especially scopolamine, cause post-synaptic competitive inhibition of muscarinic cholinergic receptor in center and peripheral areal. Kecubung also has anticholinergic effect that appears when poisoning.

The symptoms of kecubung poisoning occurs in a short time, approximately 5-10 minutes after consuming kecubung. The patients would release an excessive amount of saliva and sweat, followed by dryness of the mouth, midriasis, and trachycardia. A higher dose would cause urinary retention and hyperthermia. At this point, the patients would experience agitation and anxiety as a result of acute anticholinergics. The patient neuropsychological could be rated by the decreased orientation, chaotic mind, and hallucination. At higher doses, the patient would experience seizures, paralysis, and if not treated properly would cause mortality [11].

In the worst cases, the patient could be adminestered using Cholinesterase inhibitor physostigmine as an antidote through intravenous route. An activated charcoal (carbo adsorbent) could be administered approximately $\leq 48$ hours after consuming kecubung [10]. Each flower contains $\approx 0.65 \mathrm{mg}$ of scopolamine and $0.3 \mathrm{mg}$ of atropine. It has been reported that the lethal dose of atropine is $10 \mathrm{mg}$, so consuming 10 flowers would give a fatal effect [12].

The Ngadiwono society explained that Ciplukan (Physalis peruviana) could induce bloated stomach on the livestock. However, they added that this plants could be used as a medicine. Layyine [13] demonstrated different LC 50 value that depends on the solvent used in ciplukan extract. The solvent were ethanol, nhexane, and ethyl acetate with LC 50 value of 37,
3, and 496 ppm, respectively. This result demonstrated that ethanol extract has a great potential as antimicrobial, whereas $n$-hexane has potential as anticancer, and ethyl acetate has potential as a natural pesticide.

The antimicrobial activity on ciplukan ectract has been investigated by Silva et al. [14]. They revealed that fisalin $B$, an active compound included in steroid group, plays an important role in antimicrobial activity. Types of fisalin that usually found in ciplukan are fisalin $B, D, F$, and $G$ [15]. In the same concentration of $200 \mu \mathrm{g} / \mathrm{mL}$, fisalin B could inhibit approximately $85 \%$ microbes from total microbes that could be inhibited by other fisalin. Fisalin also acts as anti-inflammatory [16] and molluscicides [17]. Fisalin E acts as an anti-inflammatory because of its interaction with glucocorticoid receptors [18].

Ethanol extract (70\%) of ciplukan is discovered to be toxic for brine shrimp larvae according to its LC 50 that lower than $1000 \mu \mathrm{g} / \mathrm{mL}$, only 39,63 $\mu \mathrm{g} / \mathrm{mL}$. If converted, the doses used on the experiment could not exceed 5 gram $/ \mathrm{kg}$.bb [18]. Our study demonstrated that ciplukan could be useful in a certain dose. More than 5.0 gram $/ \mathrm{kg}$.bb ciplukan would cause toxicity. The kudisan sap contains chemicals called ester, euphorpen, terpenpenoid, and saponin. The exposure of this compound would cause skin irritation: such as redness, swelling, and itching. The sap exposure on the eye causes mild conjunctivitis. There is no antidotes to treat skin irritation and mild conjunctivitis caused by kudisan [19].

\section{CONCLUSION}

There were eight plants that considered as toxic by the society of Ngadiwono village. According to the scientific studies, those eight plants have toxic chemicals. Those eight toxic plants were Bedor (Girardinia palmata), Kecubung Bunga Kuning (Brugmansia suaveolens), Kecubung Bunga Putih (Brugmansia suaveolens), Jarak (Ricinus communisi), Terpasan Kuning (Cestrum elegans), Terpasan Merah (Cestrum elegans), Kudisan (Euphorbia pulcherrima), Ciplukan (Physalis angulata). The highest ICS value (45) was found in jarak plant (Ricinus communis). While the lowest ICS value was found in yellow and red Terpasan (Cestrum elegans) due to its low usage by the society. The highest Uvs value was found in kudisan $(1,68)$.

\section{ACKNOWLEDGEMENT}

This section describes gratitude to those who have helped in substance as well as financially. 


\section{REFERENCES}

[1]. Batoro, J. 2012. Etnobiologi Masyarakat Tengger Di Bromo Tengger Semeru Jawa Timur. Dissertation. Pascasarjana Program. Bogor Agricultural Institute. Bogor.

[2]. Hakim, L. (2011). Cultural Landscapes of the Tengger Highland, East Java. In Landscape Ecology in Asian Cultures (pp. 69-82). Springer Japan.

[3].Batoro, J. 2015. Mengenal Jenis-Jenis Tumbuhan dan Kegiatan Masyarakat Desa Hutan di Kawasan Bromo Tengger Semeru. Malang: Selaras.

[3]. Ahmad, I., F. Aqil, and M. Owais. 2006. Modern Phytomedicine: Turning Medical Plants into Drugs. Wiley-VCH.Verlag GMBH \& CO.KGaA. Germany.

[4]. Batoro, J. 2015. Mengenal Jenis-Jenis Tumbuhan dan Kegiatan Masyarakat Desa Hutan di Kawasan Bromo Tengger Semeru. Selaras. Malang.

[5]. Anonymous. 1999. Potret Desa Penyangga Taman Nasional Bromo Tengger Semeru. Departemen Kehutanan (Bagian Proyek Pemantapan Pengelolaan Taman Nasional Bromo Tengger Semeru Tahun Anggaran 1998/1999). Malang.

[6]. Hakim, L. (2014). Etnobotani dan Manajemen Kebun-Pekarangan Rumah: Ketahanan Pangan, Kesehatan dan Agrowisata. Selaras. Malang.

[7]. Fahrauk, F., R. Julia, and N. Neng. 2014. Uji Bioaktivitas Ekstrak Daun dan Fraksi Daun Kembang Dayang (Cestrum nocturnum Linn.) Terhadap Artemisia salina Leach dengan menggunakan Metode BSLT (Brine Shrimp Lethality Test). Proceeding Seminar Nasional Ilmu Pengetahuan dan Teknologi Universitas Jenderal Achmad Yani. 52-53.

[8]. Gupta A., K. Alok, A. Ajay, Motoki, and V. Archana. 2016. Acute accidental mass poisoning by Jatropha curcas in Agra, North India, Egypt. J Forensic http://dx.doi.org/10.1016/j.ejfs.2016.04.002

[9]. BPOM.2015. Keracunan Biji Jarak. accesed on 1 febuary 2017 http://ik.pom.go.id/v2015/qa/keracunanbiji-jarak diakses

[10]. Gopel C, Laufer C, Marcus A. 2002. Three cases of angel's trumpet tea-induced psychosis in adolescent substance abusers. Nord J Psychiatry. 56:49-52
[11]. Hall RC, Popkin MK, McHenry LE. 1977. Angel's Trumpet psychosis: a central nervous system anticholinergic syndrome. Am J Psychiatry. 134:312-314.

[12].Greene GS, Patterson SG, Warner E.1996.: Ingestion of angel's trumpet: an increasingly common source of toxicity. South Med J 1996, 89:365-369.

[13]. Layyina, H. 2014. Toksisitas Ekstrak Ciplukan (Physalis angulata) Berdasarkan Uji Letalitas Larva Udang. Departemen Kimia.Fakultas Matematika Dan Ilmu Pengetahuan Alam. Institut Pertanian Bogor.

[14]. Silva MTG, Simas SM, Batista TGFM, Cardarelli P, Tomassini TCB. 2005. Studies on antimicrobial activity, in vitro, of Physalis angulata L. (Solanaceae) fraction and physalin $B$ bringing out the importance of assay determination. Mem Inst Oswaldo Cruz. 100:779-782.Silve et al., 2015

[15]. Sa, M.S., M.N. Menezes, A.U. Krettli, I.M. Ribeiro, T.C.B. Tomassini, R.R. Santos, W.F. Azevedo, M.B.P. Soares. 2011. Antimalarial activity of physalins B, D, F, and G. J. Nat. Prod. 74. 2269-2272.

[16]. Pinto, N.B., T.C. Morais, K.M.B. Carvalo, C.R. Silva, G.M. Andrade, G.A.C. Brito, M.L. Veras, O.D.L. Pessoa, V.S. Rao, and F.A. Santos. 2010. Topical anti-inflammatory potential of physalin $E$ from Physalis angulata on experimental dermatitisin mice. Phytomedicine. 17. 740-743.

[17]. Santos, J.A.A., T.C.B. Tomassini, D.C.D. Xavier, I.M. Ribeiro, M.T.G. Silva, and Z.B.M. Filho. 2003. Molluscicidal activity of Physalis angulata $L$. extracts and fractions on Biomphalaria tenagophila (d'Orbigny, 1835) under laboratoryconditions. Mem Inst Oswaldo Cruz. 98. 425-428.

[18]. Baedowi. 1998. Timbunan Glikogen dalam Hepatosit dan Kegiatan Sel Beta Insula Pancreatisi Tikus Putih (Rattus norvegicus) Akibat Pemberian Ekstrak Daun Ciplukan, Penelitian Tanaman Obat di Beberapa Perguruan Tinggi di Indonesia IX. Departemen Kesehatan RI. Jakarta.

[19]. The American Society For Prevention of Cruelty to Animal. Toxic and Non Toxic Plant.2017.https://www.aspca.org/petcare/animal-poison-control/toxic-and-nontoxic-plants/poinsettiaAnonim, 2017? 
Table 1. List of toxic plants and the exposure effect.

\begin{tabular}{|c|c|c|c|c|c|}
\hline No. & Local Name & Scientific Name & Family & Toxic Part & The exposure side effect \\
\hline 1. & Bedor & $\begin{array}{l}\text { Girardinia } \\
\text { palmata }\end{array}$ & Urticaceae & $\begin{array}{l}\text { Thorn on the } \\
\text { leaves and } \\
\text { branches }\end{array}$ & Skin burning sensation \\
\hline 2. & Red Terpasan & Cestrum elegans & Solanaceae & $\begin{array}{l}\text { Branches, } \\
\text { leaves, and } \\
\text { flowers }\end{array}$ & $\begin{array}{l}\text { Bloated stomach and mortality on } \\
\text { livestock }\end{array}$ \\
\hline 4. & Jarak & Ricinus communis & Euphorbiaceae & $\begin{array}{l}\text { Leaves and } \\
\text { seeds }\end{array}$ & $\begin{array}{l}\text { Bloated stomach on livestock, } \\
\text { seeds could cause hallucination } \\
\text { on human }\end{array}$ \\
\hline 6. & $\begin{array}{l}\text { Yellow } \\
\text { Kecubung }\end{array}$ & $\begin{array}{l}\text { Brugmansia } \\
\text { Suaveolens }\end{array}$ & Solanaceae & $\begin{array}{l}\text { Leaves and } \\
\text { seeds }\end{array}$ & $\begin{array}{l}\text { Bloated stomach on livestock, } \\
\text { seeds could cause hallucination } \\
\text { on human }\end{array}$ \\
\hline 7. & Ciplukan & Physalis peruviana & Solanaceae & Leaves & Bloated stomach on livestock \\
\hline 8. & Kudisan & $\begin{array}{l}\text { Euphorbia } \\
\text { pulcherrima }\end{array}$ & Euphorbiaceae & $\begin{array}{l}\text { Sap from cut } \\
\text { branches }\end{array}$ & $\begin{array}{l}\text { Itchiness on the parts that } \\
\text { exposured by sap }\end{array}$ \\
\hline
\end{tabular}

Table 2. ICS value according to the benefit of toxic plant by the society of Ngadiwono Village.

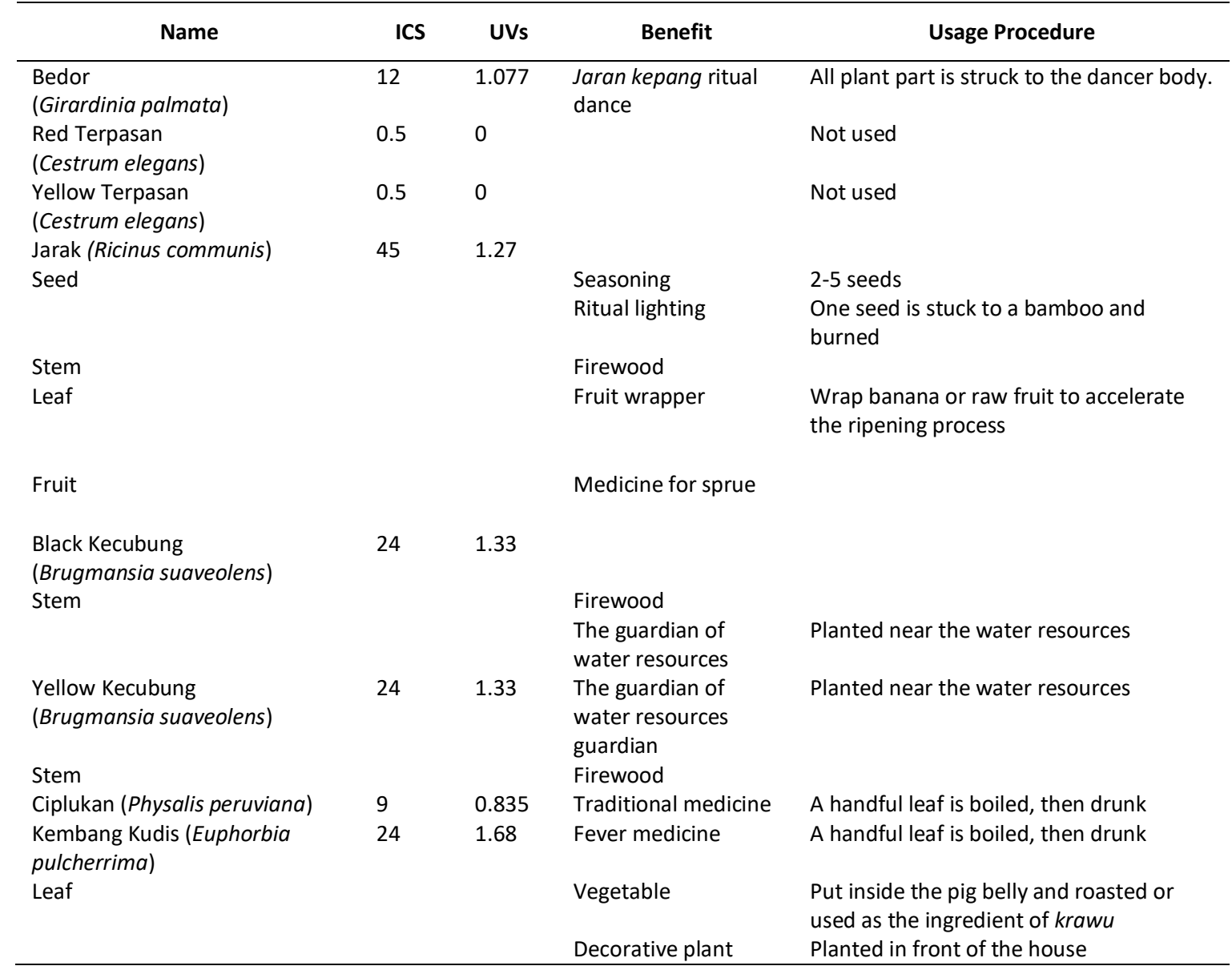

